\title{
Effects of water borne cadmium on biomarker enzymes and metallothioneins in Nile tilapia, Oreochromis niloticus
}

\author{
L.W.H.U. Chandrasekera ${ }^{1}$, A. Pathiratne ${ }^{1^{*}}$ and K. A. S. Pathiratne ${ }^{2}$ \\ ${ }^{1}$ Department of Zoology, Faculty of Science, University of Kelaniya, Kelaniya. \\ 2 Department of Chemistry, Faculty of Science, University of Kelaniya, Kelaniya.
}

Revised: 04 April 2008 ; Accepted: 15 August 2008

\begin{abstract}
Cadmium is widely used in modern industry and ranks among the most toxic metals in the aquatic ecosystems. In the present study, activities of several biomarker enzymes viz. ethoxyresorufin O-deethylase (EROD), glutathione S-transferase (GST) and cholinesterase (ChE) were determined in Nile tilapia (Oreochromis niloticus) at different waterborne $\mathrm{Cd}^{2+}$ exposure levels $(0,0.001,0.005,0.01,0.1$, and $1 \mathrm{mg} / \mathrm{L}$ for 28 days) to evaluate the potential influence of environmental cadmium on these enzymes. In addition, hepatic metallothionein (MT) levels in these fish at different waterborne $\mathrm{Cd}^{2+}$ exposure levels were also studied to evaluate their response to waterborne cadmium exposure. The results revealed that hepatic MT levels in the fish exposed to $\mathrm{Cd}^{2+}$ increased 2-26 fold depending on the exposure level and duration. Hence hepatic MT in Nile tilapia is a sensitive biomarker to indicate cadmium pollution in the natural environments. Continuous exposure of fish to $\leq 0.01$ $\mathrm{mg} / \mathrm{L}$ of $\mathrm{Cd}^{2+}$ had no significant effect on hepatic EROD, hepatic GST and brain and muscle ChE activities whereas exposure to $\geq 0.1 \mathrm{mg} / \mathrm{L} \mathrm{Cd}^{2+}$ evoked time dependent significant depression of hepatic EROD (41-55\%) activity. Brain and muscle ChE activities of the fish exposed to $1 \mathrm{mg} / \mathrm{L} \mathrm{Cd}^{2+}$ were depressed to $24-32 \%$ and $33-35 \%$ respectively. Results revealed that high concentrations of $\mathrm{Cd}^{2+}$ in the natural environments could inhibit the basal activities of the hepatic EROD and brain and muscle $\mathrm{ChE}$ in Nile tilapia affecting the normal functioning of these biomarker enzymes and influencing the biomarker response to targeted organic pollutants in the environment.
\end{abstract}

Keywords: Biomarkers, cadmium, metallothionein, tilapia.

\section{INTRODUCTION}

Environmental exposure levels of aquatic organisms to trace pollutants may be determined by measuring external levels of selected contaminants in the surrounding water and sediments. However, in order to study the fate of the chemical in the aquatic environment it is important to measure the internal dose in biota as well. It is impossible to monitor all contaminants which form a potential threat to the environment. In order to assess the quality of the aquatic environment, the impact of contaminants in terms of biochemical responses reflecting their potential impairment of physiological process can be measured in the exposed organisms such as fish ${ }^{1}$. Use of pollution indicative biomarkers is considered as a cost effective strategy for detecting contaminant exposure and diagnosing sub lethal effects in fish ${ }^{1}$.

Organic pollution indicative biomarker enzymes in fish that are of notable interest in field applications include 7-ethoxyresorufin O-deethylase(EROD), glutathione S-transferase(GST), and cholinesterases(ChE) ${ }^{1}$. CYP1A dependent monooxygenase induction measured as EROD activity has been widely used as a sensitive indicator of exposure to anthropogenic organic contaminants with a planar configuration such as polynuclear aromatic hydrocarbons and polychlorinated biphenyls ${ }^{1,2}$. GST which plays a key role in catalyzing the conjugation in phase II detoxification pathways of different xenobiotics, is induced by limited number of natural and synthetic compounds ${ }^{3}$. This enzyme is also involved in antioxidant defense response ${ }^{3}$. $\mathrm{ChE}$ in fish has been recognized as a biomarker for neurotoxic contaminations such as organophosphorous and carbamate pesticides in aquatic environments ${ }^{1,4}$. The inhibition of brain $\mathrm{ChE}$ can affect the proper neurotransmission at the cholinergic synapses $^{1,4}$.

Metallothioneins (MT) are a group of low molecular weight cystein rich intracellular metal binding proteins in animals. They function in regulation of essential metals such as copper and zinc and detoxification of 
non-essential metals such as cadmium and lead ${ }^{5,6}$. MT is induced in some animals following exposure to these metals and there is some evidence that fish MT induction is a biomarker of metal contamination in the aquatic environments ${ }^{5,6}$.

Fish populations residing in polluted water bodies are often exposed to complex mixtures of anthropogenic contaminants including organic pollutants and heavy metals. In order to formulate accurate conclusions about the chemical exposure using biomarker approach, influence of other environmental contaminants on biomarker responses that are indicative of specific chemical groups should be examined. Heavy metals exert their toxicity by multiple mechanisms including inhibition of enzymes containing sulfhydryl groups in or near their active sites and generation of oxygen reactive species $^{7}$. Hence it can be assumed that heavy metal exposure may have a potential to influence biomarker enzymes of organic pollution.

Cadmium which is widely used in modern industry, ranks among the most toxic metals in the aquatic ecosystems. Nile tilapia (Oreochromis niloticus) which is a culturable fish for human consumption, has been suggested as a suitable species for testing pollutant impact especially in tropical water bodies due to its hardy nature, high abundance and wide distribution in the tropical regions. However the information on influence of environmentally relevant waterborne cadmium levels on biomarkers in Nile tilapia is meager. Therefore, the objective of the present study was to evaluate the response of EROD, and GST in liver tissues and ChE in brain and muscle tissues of Nile tilapia to water borne sub-lethal cadmium exposures including range of concentrations that may occur in natural environments. The MT level in these fish was also evaluated to assess its potential role as a biomarker of cadmium exposure.

\section{METHODS AND MATERIALS}

Fish: Oreochromis niloticus, (Nile tilapia) samples were obtained from the Rambadagalla fish breeding station, National Aquaculture Development Authority of Sri Lanka. Fish were allowed to acclimate to laboratory conditions in fiberglass tanks (one fish per $12 \mathrm{~L}$ of water) filled with continuously aerated aged tap water under natural photoperiod for five weeks prior to the experiments. Half of the water in each tank was exchanged with aged tap water every 4 to $5 \mathrm{~d}$. During the acclimation period, fish were daily fed with commercial fish food pellets (Prima, Sri Lanka) at $1 \%$ of the body weight.
Cadmium exposure: Female Nile tilapia (18.9 $\pm 2.3 \mathrm{~cm}$ in total length, $87.3 \pm 5.6 \mathrm{~g}$ in body weight, $\mathrm{n}=180)$ were distributed randomly to six groups of 30 fish (10 fish per aquarium, three aquaria for each group). The first group received no treatment and served as the control. Groups 2, 3, 4, 5 and 6 were exposed to $\mathrm{CdCl}_{2}$ at nominal $\mathrm{Cd}^{2+}$ concentrations of $0.001,0.005,0.01,0.1$ and $1 \mathrm{mg} / \mathrm{L}$ respectively for $28 \mathrm{~d}$. The $96 \mathrm{~h} \mathrm{LC}_{50}$ of $\mathrm{CdCl}_{2}$ was reported to be $18.58 \mathrm{mg} / \mathrm{L}$ for juvenile Nile tilapia ${ }^{8}$. Hence the $\mathrm{Cd}^{2+}$ concentrations used in this study could be considered as sub-lethal concentrations.

Fish were exposed to $\mathrm{Cd}^{2+}$ under semi-static conditions for $28 \mathrm{~d}$ at a density of one fish per $14 \mathrm{~L}$ of the test medium. Control fish were maintained in aged tap water at comparable densities. Fish were fed with the commercial food pellets daily at $1 \%$ of the body weight. Water in the aquaria were aerated continuously and exchanged completely after every $3 \mathrm{~d}$. Concentration of $\mathrm{Cd}^{2+}$ was renewed immediately after renewal of the water. Water quality parameters [temperature, $\mathrm{pH}$, and dissolved oxygen concentration (DO)] in the aquaria were monitored intermittently using water quality monitors (HACH Company, USA) and were within desirable levels for fish: temperature $27.8-28.9^{\circ} \mathrm{C}$; $\mathrm{pH} 6.9$ - 7.2; DO $4.4-5.1 \mathrm{mg} / \mathrm{L}$. No mortality of fish was observed during the experimental period.

Six fish from each group were randomly sampled from the three replicate tanks after 7, 14, 21 and $28 \mathrm{~d}$ of $\mathrm{Cd}^{2+}$ exposure for biomarker assessments. Fish were sacrificed by severing the spinal cord. Brain and a piece of muscle from the lateral side were removed and stored frozen at $-80^{\circ} \mathrm{C}$ until analysis of $\mathrm{ChE}$ activity. Liver tissue from each fish was divided into two portions and stored frozen separately at $-80^{\circ} \mathrm{C}$. One portion of liver was used for MT determinations and the other for preparation of microsomes and cytosol. Analysis of biomarkers was carried out within three weeks of the storage.

Analysis of cadmium in water and fish food: Water samples from the control aquaria and $\mathrm{Cd}^{2+}$ added aquaria were taken randomly on three occasions (on $7^{\text {th }}, 14^{\text {th }}$ and $21^{\text {st }}$ day) immediately before exchange of the aquaria water and immediately after subsequent renewal of $\mathrm{Cd}^{2+}$ concentrations in the respective aquaria. The water replacement was combined with the renewal of $\mathrm{Cd}^{2+}$ concentrations in the aquaria. The $\mathrm{pH}$ of the water samples were adjusted to 1-2 using concentrated nitric acid and total cadmium concentration in water was analyzed by graphite furnace atomic absorption spectrometry (GBC 932 plus Atomic Absorption Spectrometer equipped with GBC GF 3000 Graphite Furnace system and GBC PAL 3000 auto sampler). Samples of fish food were subjected 
to dry ashing 9 and the digested samples were analysed using graphite furnace spectrometry.

Tissue preparation for enzyme assays: Microsomal and cytosolic fractions of liver tissues were prepared by differential centrifugation. Liver tissues were excised and a $20 \%$ homogenate $(\mathrm{w} / \mathrm{v})$ was prepared in ice-cold $100 \mathrm{mM} \mathrm{KH}_{2} \mathrm{PO}_{4} / \mathrm{K}_{2} \mathrm{HPO}_{4}$ buffer $\mathrm{pH} 7.6$ containing 0.25 $\mathrm{M}$ sucrose, $15 \%(\mathrm{v} / \mathrm{v})$ glycerol using the Ultra-Turrax T25 tissue homogenizer (IKA Labortechnik, Germany) at medium speed for $20 \mathrm{~s}$. The homogenate was centrifuged at $12,000 \mathrm{~g}$ for $30 \mathrm{~min}$ at $4^{\circ} \mathrm{C}$ and the resultant supernatant was further centrifuged at $100,000 \mathrm{~g}$ at $4^{\circ} \mathrm{C}$ for 90 min using the ultra speed centrifuge (Sorvall Ultra 80) to sediment the microsomes. Aliquots of the $100,000 \mathrm{~g}$ supernatant (cytosol) were removed from the floating fatty layer for immediate GST assay. The microsomal pellets were resuspended in $100 \mathrm{mM} \mathrm{KH}_{2} \mathrm{PO}_{4} / \mathrm{K}_{2} \mathrm{HPO}_{4}$ buffer $\mathrm{pH} 7.6$ containing $1.15 \% \mathrm{KCl}$ and $20 \%(\mathrm{v} / \mathrm{v})$ glycerol and were stored at $-80^{\circ} \mathrm{C}$ for EROD assay. The enzyme source for $\mathrm{ChE}$ assay was prepared by homogenizing the brain or muscle tissue of individual fish in ice-cold $100 \mathrm{mM}$ $\mathrm{KH}_{2} \mathrm{PO}_{4} / \mathrm{K}_{2} \mathrm{HPO}_{4}$ buffer, $\mathrm{pH} 8.0$ (20 mg tissue: $1 \mathrm{~mL}$ of the buffer) for immediate enzyme assay. All preparation steps of the enzyme sources were carried out on ice.

EROD, GST and ChE assays: EROD activity in the liver microsomes was determined spectrophotometrically as described in Klotz et al. ${ }^{10}$ with some modifications of the reaction conditions. The reaction mixture in a final volume of $1 \mathrm{~mL}$ contained $100 \mathrm{mM} \mathrm{NaH} \mathrm{PO}_{4} / \mathrm{K}_{2} \mathrm{HPO}_{4}$ buffer $\mathrm{pH} 7.6$ containing $1.15 \% \mathrm{KCl}, 50 \mu \mathrm{L}$ liver microsomes, $2 \mu \mathrm{M}$ of 7-ethoxyresorufin and $0.5 \mathrm{mM}$ of Nicotinamide Adenine Dinucleotide Phosphate reduced form (NADPH). The enzyme activity was measured at $572 \mathrm{~nm}$ as a kinetic assay at $30^{\circ} \mathrm{C}$. The enzyme activity is expressed as pmoles resorufin $\mathrm{produced} / \mathrm{min} / \mathrm{mg}$ protein.

GST in the liver cytosol fraction was measured by following the conjugation of glutathione at $340 \mathrm{~nm}$ using 1-chloro-2,4-dinitrobenzene(CDNB) as substrate ${ }^{11}$. The final reaction mixture in a volume of $2.25 \mathrm{~mL}$ contained $2 \mathrm{~mL}$ of $100 \mathrm{mM} \mathrm{NaH} \mathrm{PO}_{4} / \mathrm{K}_{2} \mathrm{HPO}_{4}$ buffer $\mathrm{pH} 6.75,50 \mu \mathrm{L}$ of cytosol, $1.25 \mathrm{mM} \mathrm{CDNB}$ and $1 \mathrm{mM}$ reduced glutathione. The reaction was measured at $25^{\circ} \mathrm{C}$ for $2 \mathrm{~min}$. The enzyme activity is expressed as nmoles thioether produced $/ \mathrm{min} / \mathrm{mg}$ protein.

ChE activities in the tissue homogenates were determined at $25{ }^{\circ} \mathrm{C}$ following the method of Ellman et al. ${ }^{12}$ with some modifications. The tissue homogenate $(100 \mu \mathrm{L})$ was added to a cuvette containing $2.8 \mathrm{~mL}$ of $100 \mathrm{mM} \mathrm{NaH}_{2} \mathrm{PO}_{4} / \mathrm{K}_{2} \mathrm{HPO}_{4}$ buffer $\mathrm{pH} 8.0$ and $100 \mu \mathrm{L}$ of 10 M 5, 5'-dithiobis-2-nitrobenzoic acid. The contents were then mixed and the absorbance was read at 412 $\mathrm{nm}$ at $10 \mathrm{~s}$ intervals for $1 \mathrm{~min}$. Then $40 \mu \mathrm{L}$ of $0.076 \mathrm{M}$ acetylthiocholine iodide was added to the reaction mixture and the absorbance was read for another one minute. The $\mathrm{ChE}$ activity is expressed as nmoles of 5-thio-2-nitrobenzoic acid produced $/ \mathrm{min} / \mathrm{mg}$ protein.

Proteins present in the liver microsomes and cytosol and brain and muscle homogenates were determined according to the method of Lowry et al. ${ }^{13}$ with bovine serum albumin as the standard.

Metallothionein determination: Metallothionein levels in the liver tissues of the control and cadmium exposed Nile tilapia were determined using Brdicka procedure as described by Olafson and Olsson ${ }^{14}$. A $50 \mathrm{mg}$ of liver tissue was homogenized in $2.5 \mathrm{~mL}$ of ice-cold $10 \mathrm{mM}$ Tris $\mathrm{HCl}$ buffer, $\mathrm{pH} 8.1$ and, centrifuged at $10,000 \mathrm{~g}$ for $20 \mathrm{~min}$ at $4^{\circ} \mathrm{C}$. The resultant supernatant was heat denatured at $95^{\circ} \mathrm{C}$ for $5 \mathrm{~min}$ and the denatured samples were recentrifuged at $10,000 \mathrm{~g}$ for $40 \mathrm{~min}$ at $4^{\circ} \mathrm{C}$ to remove heat denatured proteins. MT in the resultant supernatant was determined by differential pulse polarography at $25^{\circ} \mathrm{C}$ (EG \& G Princeton Applied Research Corporation model 394 electrochemical trace analyzer equipped with the model 303A Static Mercury Drop Electrode). Rabbit MT-I was used as the MT standard. MT levels are expressed as $\mu \mathrm{g} / \mathrm{g}$ liver based on the average molecular weight of 6500 dalton.

Statistical Analysis: $\mathrm{Cd}^{2+}$ exposure concentration effects on each biomarker responses of the fish were analyzed separately by one way analysis of variance (ANOVA, $\mathrm{p}<0.05$ ). Where differences were significant, multiple comparisons were carried out by the Tukey's test ${ }^{15}$.

Table 1: Nominal and measured concentrations of cadmium in test water

\begin{tabular}{llc}
\hline & \multicolumn{2}{c}{$\begin{array}{c}\text { Measured concentration of } \\
\text { cadmium }(\mathrm{mg} / \mathrm{L})\end{array}$} \\
\cline { 2 - 3 } $\begin{array}{c}\text { Nominal concentration } \\
\text { of } \mathrm{Cd}^{2+}(\mathrm{mg} / \mathrm{L})\end{array}$ & On the 1st day & $\begin{array}{c}\text { After } 3 \text { days of } \\
\text { renewal } \\
\text { (prior to next renewal) }\end{array}$ \\
\hline 0 (Control) & $\mathrm{ND}$ & $\mathrm{ND}$ \\
0.001 & $0.001 \pm 0.0 .0004$ & $\mathrm{ND}$ \\
0.005 & $0.005 \pm 0.001$ & $0.003 \pm 0.002$ \\
0.01 & $0.009 \pm 0.03$ & $0.007 \pm 0.004$ \\
0.10 & $0.085 \pm 0.010$ & $0.062 \pm 0.012$ \\
1 & $0.858 \pm 0.37$ & $0.558 \pm 0.46$ \\
\hline
\end{tabular}

Test water and cadmium concentration were renewed every 3 days. Data are presented as mean \pm SD of three random sampling times. ND $=$ not detected 


\section{RESULTS}

\section{Concentrations of cadmium in test water and fish food}

Measured concentrations of cadmium in the test water are presented in Table 1. Mean values of the initial measured exposure concentrations differed between $85-100 \%$ of the nominal concentrations just after the renewal. Hence, exposure concentrations are reported as nominal concentrations. When the test water was allowed to remain in the fish aquaria for three days, cadmium was not detected in the aquaria which initially contained $0.001 \mathrm{mg} / \mathrm{L}$ of cadmium whereas the measured concentration in the other aquaria dropped to $56-70 \%$ of the nominal concentrations of cadmium depending on the initial cadmium level. No detectable levels of cadmium were found in the samples of fish food.

\section{Effect of cadmium on hepatic EROD and GST}

Exposure to $\leq 0.01 \mathrm{mg} / \mathrm{L}$ cadmium for 28 days had no significant effect on hepatic EROD activity but 0.1 or $1 \mathrm{mg} / \mathrm{L}$ cadmium exposure evoked a significant depression of the enzyme activity until 14 days (Figure 1). EROD activity of the fish exposed to $0.1 \mathrm{mg} / \mathrm{L}$ cadmium on $7^{\text {th }}$, and $14^{\text {th }}$ day of exposure were $55 \%$, and $52 \%$, of the controls respectively (45-48\% depression). Corresponding values for the fish exposed to $1 \mathrm{mg} / \mathrm{L}$ cadmium were 45\%, and 59\% (55-41\% depression). Cadmium induced inhibition of EROD activity restored to the levels of controls by 21 days. Cadmium exposure levels used in the present study had no significant effect on the hepatic GST activities of the fish (Figure 1).

\section{Effects of cadmium on ChE}

Exposure of fish to $0.001-0.1 \mathrm{mg} / \mathrm{L}$ cadmium for 28 days had no significant effect on brain and muscle $\mathrm{ChE}$ of the exposed fish (Figure 2). However exposure of the fish to $1 \mathrm{mg} / \mathrm{L}$ cadmium caused a significant depression of brain ChE levels during the study period (24-32\% of the controls). A significant inhibition of muscle $\mathrm{ChE}$ activity was also detected in the fish exposed to $1 \mathrm{mg} / \mathrm{L}$ cadmium. Muscle $\mathrm{ChE}$ activities of these fish were reduced to $33-35 \%$ of the controls during the experimental period. The brain and $\mathrm{ChE}$ activities of the fish remained inhibited even on $28^{\text {th }}$ day after the exposure to $1 \mathrm{mg} / \mathrm{L}$ cadmium.

\section{Effect of cadmium on hepatic MT}

Hepatic MT levels of control fish and the fish exposed to different concentrations of waterborne cadmium are given in Table 2. Exposure of fish to $0.001 \mathrm{mg} / \mathrm{L}$ of cadmium had no significant effect on MT level during the exposure period ( $\mathrm{p}>0.05$ ). Exposure of fish to 0.005 - $1 \mathrm{mg} / \mathrm{L}$ resulted in significantly elevated hepatic MT levels depending on the exposure duration and the concentration.

\section{DISCUSSION}

The present study demonstrates the effect of sub-lethal cadmium exposure for 28 days on MTand several pollution indicative biomarker enzymes of Nile tilapia under three low concentration levels and two high exposure levels of cadmium. The lower concentrations $(0.001-0.01 \mathrm{mg} / \mathrm{L})$ of cadmium used to expose Nile tilapia in the present study were within the environmentally relevant levels in low or moderately polluted water bodies ${ }^{16-19}$.

Table 2: Hepatic metallothionein (MT) levels in Nile tilapia exposed to different concentrations of water borne $\mathrm{Cd}^{2+}$ for 28 days

\begin{tabular}{lllll}
\hline $\begin{array}{l}\mathrm{Cd}^{2+} \\
(\mathrm{mg} / \mathrm{L})\end{array}$ & \multicolumn{4}{c}{$\mathrm{MT}$ M $(\mu \mathrm{gg} / \mathrm{g})$} \\
\cline { 2 - 5 } $0($ Control $)$ & $14.2 \pm 3.5^{\mathrm{a}}$ & $15.8 \pm 4.7^{\mathrm{a}}$ & $14.9 \pm 4.2^{\mathrm{a}}$ & \multicolumn{1}{c}{$15.4 \pm 2.7^{\mathrm{a}}$} \\
0.001 & $13.9 \pm 8.2^{\mathrm{a}}$ & $14.2 \pm 3.1^{\mathrm{a}}$ & $15.7 \pm 3.3^{\mathrm{a}}$ & $15.7 \pm 2.5^{\mathrm{a}}$ \\
0.005 & $15.3 \pm 4.1^{\mathrm{a}}$ & $13.9 \pm 4.2^{\mathrm{a}}$ & $18.3 \pm 1.7^{\mathrm{b}}$ & $19.3 \pm 2.6^{\mathrm{b}}$ \\
0.01 & $14.6 \pm 8.0^{\mathrm{a}}$ & $26.0 \pm 4.1^{\mathrm{b}}$ & $36.7 \pm 4.5^{\mathrm{c}}$ & $42.7 \pm 2.5^{\mathrm{c}}$ \\
& - & $(165 \%)$ & $(246 \%)$ & $(277 \%)$ \\
0.10 & $23.6 \pm 5.5^{\mathrm{b}}$ & $53.1 \pm 7.6^{\mathrm{c}}$ & $104.5 \pm 7.7^{\mathrm{d}}$ & $149.1 \pm 17.0^{\mathrm{d}}$ \\
& $(166 \%)$ & $(336 \%)$ & $(701 \%)$ & $(1112 \%)$ \\
1 & $84.9 \pm 12.6^{\mathrm{c}}$ & $113.7 \pm 15.1^{\mathrm{d}}$ & $131.1 \pm 14.4^{\mathrm{d}}$ & $350.7 \pm 7.8^{\mathrm{e}}$ \\
& $(598 \%)$ & $(720 \%)$ & $(879 \%)$ & $(2617 \%)$ \\
\hline
\end{tabular}

Data are presented as mean $\pm \mathrm{SD}, \mathrm{n}=6$ fish. Figures in parentheses indicate the percent of MT levels in the fish exposed to higher cadmium concentrations in comparison to the mean value of the controls. In a column, data indicated with different superscripts are significantly different from each other (ANOVA, Tukey's test, $\mathrm{p}<0.05$ ). 


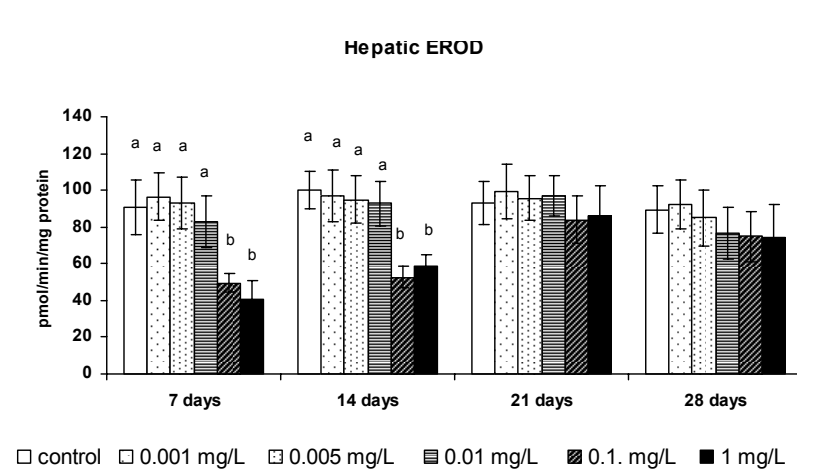

$\square$ control $\square 0.001 \mathrm{mg} / \mathrm{L} \quad \square 0.005 \mathrm{mg} / \mathrm{L} \quad$ 目 $0.01 \mathrm{mg} / \mathrm{L} \quad 0.1 . \mathrm{mg} / \mathrm{L} \quad \square 1 \mathrm{mg} / \mathrm{L}$

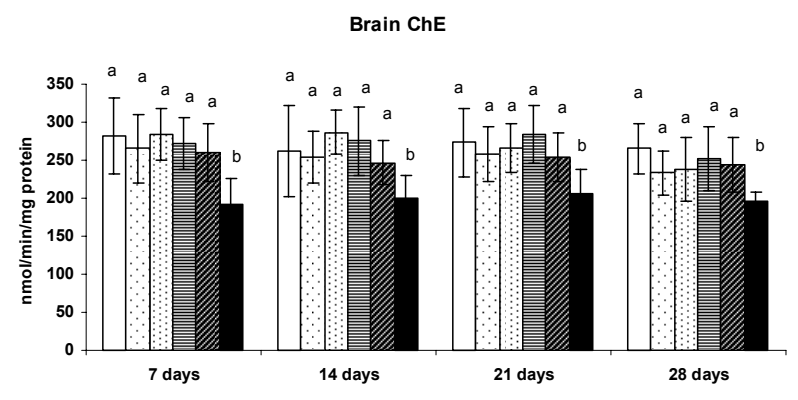

$\square$ control $\square 0.001 \mathrm{mg} / \mathrm{L} \square 0.005 \mathrm{mg} / \mathrm{L} \quad$ 目 $0.01 \mathrm{mg} / \mathrm{L} \quad 0.1 \mathrm{mg} / \mathrm{L} \quad 1 \mathrm{mg} / \mathrm{L}$

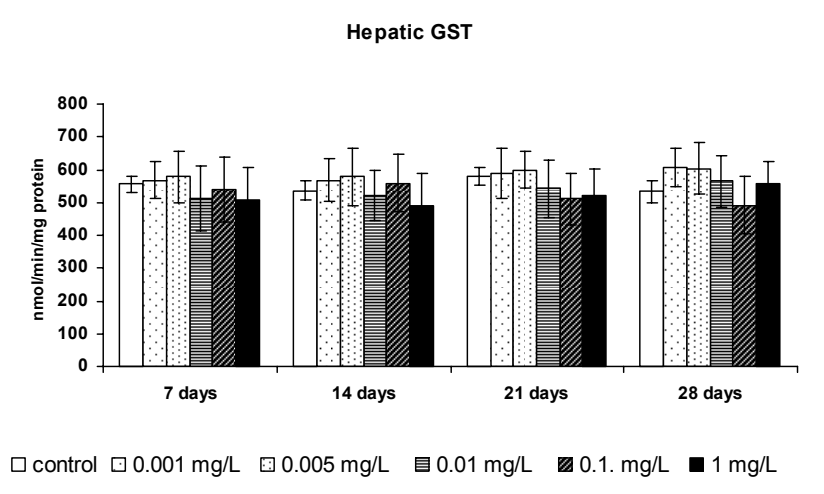

Figure 1: Effect of waterborne cadmium exposure on hepatic Ethoxyresorufin O-deethylase (EROD) and Glutathione S-transferase (GST) activities of Nile tilapia. Results are presented as mean \pm SD of 6 fish. For specific durations of exposure, bars indicated with different letters are significantly different from each other (ANOVA, Tukey's test, $\mathrm{p}<0.05$ ). For other time durations, bars not shown with letters indicate that differences are not significant in different exposure groups (ANOVA, p>0.05).

In several species of fish, MT levels have been demonstrated to increase in a dose-responsive and/ or time responsive manner after intraperitoneal (ip) administration of heavy metals ${ }^{20-22}$. Cadmium inducible MT has been identified from Mozambique tilapia, Oreochromis mossambicus after administration of 6-7 $\mathrm{mg} / \mathrm{L}$ cadmium for 13-14 days or injection with $0.2 \mathrm{mg} /$ $\mathrm{kg} \mathrm{CdCl}_{2}$ every 2 days for 3 days $^{23}$. Studies on metal induction of tilapia MT gene expression in vivo showed tilapia MT mRNA is responsive to the studied metals including cadmium ${ }^{24}$. The present study demonstrates that MT synthesis is induced in Nile tilapia, Oreochromis niloticus after exposure to $\geq 0.005 \mathrm{mg} / \mathrm{L}$ levels of waterborne cadmium which lead to significantly higher concentrations of MT in liver tissues. Hepatic MT concentrations in these fish increased as a function of time and exposure concentration indicating that tilapia

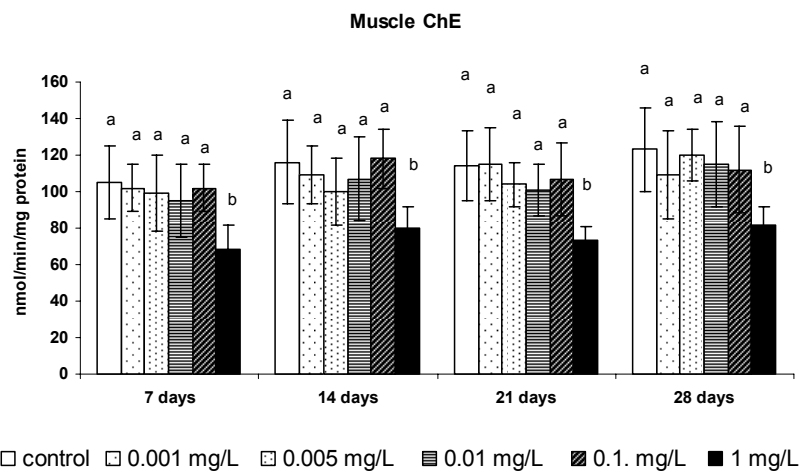

Figure 2: Effect of waterborne cadmium exposure on brain and muscle Cholinesterase (ChE) activities of Nile tilapia. Results are presented as mean $\pm \mathrm{SD}$ of 6 fish. For specific durations of exposure, bars indicated with different letters are significantly different from each other (ANOVA, Tukey's test, $\mathrm{p}<0.05)$. For other time durations, bars not shown with letters indicate that differences are not significant in different exposure groups (ANOVA, $\mathrm{p}>0.05$ ).

hepatic MT levels are a sensitive biomarker of exposure to environmental levels of waterborne cadmium. In a previous study, exposure of carp to $1 \mathrm{mg} / \mathrm{L}$ cadmium for 7 days caused no significant increase in hepatic $\mathrm{MT}^{25}$. In the present study, nearly six fold increase in hepatic MT was observed in Nile tilapia when the fish were exposed to $1 \mathrm{mg} / \mathrm{L}$ cadmium for 7 days. However, exposure of fish to the lowest nominal cadmium concentration tested, $0.001 \mathrm{mg} / \mathrm{L}$, had no significant effect on hepatic MT during the exposure period of 28 days.

Ueng et $a .^{22}$ reported that single ip administration of $\mathrm{CdCl}_{2}$ at 3,4 , and $10 \mathrm{mg} / \mathrm{kg}$ resulted in 12-13 fold increase in hepatic MT in tilapia. Maximum induction of tilapia MT occurred near $2 \mathrm{mg} / \mathrm{kg}$ of $\mathrm{CdCl}_{2}$ and that MT did not increase proportionately with doses greater than $2 \mathrm{mg} / \mathrm{kg}$. A biphasic dose-response was also observed 
in plaice ${ }^{21}$ treated with $\mathrm{CdCl}_{2}$ exceeding $0.82 \mathrm{mg} / \mathrm{kg}$. It has been suggested that administration of high doses of cadmium lead to excess cellular cadmium which in turn decreased MT induction ${ }^{22}$. In the present study, such a biphasic dose-response was not observed in Nile tilapia even after exposure to $1 \mathrm{mg} / \mathrm{L}$ of waterborne cadmium, the highest exposure concentration tested. The levels of cadmium accumulated in the tissues of Nile tilapia during waterborne exposure may have been too low to induce such a response.

Heavy metals including cadmium exert their toxicity by multiple mechanisms such as inhibition of enzymes containing sulfhydryl groups in or near their active sites or generation of reactive oxygen species. In vitro studies on effects of $\mathrm{Hg}^{2+}, \mathrm{Zn}^{2+}, \mathrm{Ni}^{2+}$ and $\mathrm{Cd}^{2+}$ on EROD activities in leaping mullet showed that all the metal ions caused inhibition of the initial velocity of the reaction but $\mathrm{Hg}^{2+}$ and $\mathrm{Cd}^{2+}$ exhibited much higher inhibitory effect at lower concentrations than the other metal ions ${ }^{26}$. Ueng et $a l^{22}$ reported that injection of tilapia with $\mathrm{CdCl}_{2}$ at $2 \mathrm{mg} / \mathrm{kg}$ had no effect on in vivo EROD or Cytochrome P450 dependent enzyme system and suggested that induction of MT protects the microsomal monooxygenases from the adverse effect of metals. In plaice, ip administration with $\mathrm{CdCl}_{2}$ at doses lower than $2 \mathrm{mg} / \mathrm{kg}$ did not cause apparent induction of MT but decreased liver EROD and other monooxygenase activities at 24 hours following treatment $t^{20}$. In the present study, exposure of fish to $0.001-0.01 \mathrm{mg} / \mathrm{L}$ of cadmium, had no significant effect on hepatic EROD activities but significant inhibition of the activities was observed when the fish were exposed to higher concentrations of cadmium $(0.1$ and $1 \mathrm{mg} / \mathrm{L})$ until 14 days. Cytochrome P 450 reductase contains one essential cystein residue at or near NADPH binding site and binding of cadmium or other metals to the reductase may inactivate the reductase thus the EROD activity ${ }^{26}$. In the present study, continuous exposure of Nile tilapia to 0.1 and $1 \mathrm{mg} / \mathrm{L}$ of cadmium for 21 to 28 days, caused production of high levels of hepatic MT which seems to ameliorate the inhibitory effects of cadmium on hepatic EROD activities 21 days exposure onwards.

A study on exposure of tilapia Oreochromis mossambicus to $5 \mathrm{mg} / \mathrm{L}$ cadmium for 30 days on glutathione dependent enzymes and antioxidatant enzymes showed that these antioxidants provide a first line of defense against cadmium before the induction of any MT synthesis occurs ${ }^{27}$. They found an increase of GST nearly by $80 \%$ on the $15^{\text {th }}$ day of exposure period. In the present study, exposure of Nile tilapia to much lower concentrations of cadmium $(0.001-1 \mathrm{mg} / \mathrm{L})$ had no significant effect on hepatic GST activities.
Payne etal ${ }^{28}$ suggested thatheavymetals would be expected to have little potential for $\mathrm{ChE}$ enzyme inhibition. In a previous study, it was found that Nile tilapia pretreated with $0.5 \mathrm{mg} / \mathrm{kg}$ cadmium had no significant effect on brain acetylcholinesterase activity or acute toxicity (96 $\mathrm{LC}_{50}$ ) for malathion (an organophosphate) exposure ${ }^{29}$. The present study found that brain and muscle $\mathrm{ChE}$ activities were not significantly affected by cadmium when Nile tilapia fish were exposed to $0.001-0.1 \mathrm{mg} / \mathrm{L}$ cadmium for 28 days. The concentration of cadmium in brain tissue may not be high enough to cause a significant depression of $\mathrm{ChE}$ activities when the fish were exposed to $0.001-0.1 \mathrm{mg} / \mathrm{L}$ of cadmium. However, in the present study, brain ChE (24-32\%) and muscle ChE (33-35\%) were depressed significantly after exposure of fish to the highest cadmium concentration $(1 \mathrm{mg} / \mathrm{L})$ for 28 day. Prolong exposure to high levels of cadmium may have accumulated enough cadmium in the brain and muscle tissues to cause a significant inhibition of ChE. Coğun et $a l .{ }^{30}$ determined the accumulation of cadmium in small and large size young Nile tilapia after exposure to 0.1 and $1 \mathrm{mg} / \mathrm{L}$ of cadmium for 30 days and found that muscle accumulated 2.02 and 2.5 (mean values in $\mathrm{mg} / \mathrm{kg}$ dry weight) of cadmium respectively during the exposure. Corresponding cadmium values for the liver were 114.5 and 274.9 (mean values in $\mathrm{mg} / \mathrm{kg}$ dry weight) which shows that muscle accumulated very low levels of cadmium compared to the liver tissue of the fish. Accumulation rates of cadmium in brain tissues of Nile tilapia are not available. It can be expected that integrity of the blood-brain barrier would afford some protection against entrance of cadmium in the brain.

In conclusion, the present study showed that hepatic MT in Nile tilapia is a sensitive biomarker to indicate moderate to high levels of waterborne cadmium exposure in the environment. Moreover, exposure of Nile tilapia to higher levels of waterborne cadmium caused inhibition of brain and muscle ChE (at $1 \mathrm{mg} / \mathrm{L}$ of cadmium), and hepatic EROD enzymes (at $\geq 0.1 \mathrm{mg} / \mathrm{L}$ cadmium) depending on the exposure concentration and the time. Results revealed that high concentrations of $\mathrm{Cd}^{2+}$ in the natural environments could inhibit the basal activities of the hepatic EROD and brain and muscle $\mathrm{ChE}$ in Nile tilapia affecting the normal functioning of these biomarker enzymes and influencing the biomarker response to targeted organic pollutants in the environment. As, activities of EROD and GST in liver tissues and $\mathrm{ChE}$ in brain and muscle tissues in Nile tilapia were not significantly affected by environmentally more relevant concentrations of $\mathrm{Cd}^{2+}(\leq 0.01 \mathrm{mg} / \mathrm{L})$, these biomarkers of the fish may serve as sensitive measures of exposure to specific organic pollutants while the fish populations 
are also exposed concurrently to low levels of cadmium in the natural environments. Further studies on effects of co-exposure of cadmium and specific organic pollutants on biomarker enzymes of the fish are needed to investigate this aspect further.

\section{Acknowledgement}

This work was financially supported by the National Science Foundation of Sri Lanka (RG/2003/ZOO/05).

\section{References}

1. van der Oost R., Beyer J., \& Vermeulan N.P.E. (2003). Fish bioaccumulation and biomarkers in environmental risk assessment: a review. Environmental Toxicology \& Pharmacology 13(2): 57-149.

2. Stegeman J.J. \& Hahn M.E. (1994). Biochemistry and Molecular biology of monooxygenases: Current perspective on forms, functions and regulation of cytochrome $\mathrm{P} 450$ in aquatic species. In: Aquatic Toxicology: Molecular, Biochemical and Cellular Perspectives. (Eds. D.C. Malin, \& G.K. Ostrander). pp.87-206. Lewis Publishers, CRC Press, New York.

3. George S.G. (1994). Enzymology and molecular biology of phase II xenobiotic conjugating enzymes in fish, In: Aquatic Toxicology: Molecular, Biochemical and Cellular Perspective. (Eds. D.C. Malin, \& G.K. Ostrander). pp. 37-85. Lewis Publishers, CRC Press, New York.

4. Fulton M.H. \& Key P.B. (2001). Acetylcholinesterase inhibition in esuarine fish and invertebrates and indicator of organophosphorus insecticide exposure and effects. Environmental Toxicology \& Chemistry 20(1): 37-45.

5. Roesijadi G. (1992). Metallothioneins in metal regulation and toxicity in aquatic animals. Aquatic Toxicology 22 (2):81-114.

6. Roesijadi G. \& Robinson W.E. (1994). Metal regulation in aquatic animals: mechanisms of uptake, accumulation and release. In: Aquatic Toxicology: Molecular, Biochemical and Cellular Perspectives. (Eds. D.C. Malins \& G.K. Ostrander), pp.387-420. Lewis Publishers, CRC Press, New York.

7. Wright D.A. \& Welbourne P. (2002). Environmental Toxicology, Cambridge University Press, UK.

8. Almeida J.A., Diniz Y.S., Marques S.F.G., Faine L.A., Ribas B.O., Burneika R.C. \& Novelli E.L.B. (2002). The use of the oxidative stress responses as biomarkers in Nile tilapia (Oreochromis niloticus) exposed to in vivo cadmium contamination. Environmental International 27 (8):673-679.

9. Jorhem L. (1993). Determination of metals in food stuffs by atomic absorption spectrometry after dry ashing. NMKL laboratory study of lead, cadmium, zinc, copper, iron, chromium and nickel. Journal of AOAC International 76(4):798-813.

10. Klotz A.V., Stegeman J.J. \& Walsh C. (1984). An alternative 7-ethoxyresorufin )-deethylase activity assay; a continuous visible spectrometric method for measurement of cytochrome P-450 monooxygenase activity. Analytical Biochemistry 140(1):138-145.

11. Habig W.H., Pabst M.J. \& Jakoby W.B. (1974). Glutathione S-transferases. The first enzymatic step in mercapturic acid formation. Journal of Biological Chemistry 249 (22):7130-7139.

12. Ellman G.L., Coutney K.D., Anders V. Jr. \& Featherstone R. M. (1961). A new and rapid colourimetric determination of acetylcholinesterase activity. Biochemical Pharmacology 7(2): 85-95.

13. Lowry H., Rosebrough N.J., Farr A.L. \& Randall R.J. (1951). Protein measurement with the Folin phenol reagent. Journal of Biological Chemistry 193(1): 265-275.

14. Olafson R.W. \& Olsson P. (1991). Electrochemical detection of metallothionein. Methods in Enzymology 205:205-213

15. Zar J.H. (1999). Biostatistical Analysis. $4^{\text {th }}$ edition. Prentice Hall, Upper Saddle River, New Jersey, USA.

16. Klavins M., Briede A., Rodinov V. Kokorite I., Parele E. \& Klavina I. (2000). Heavy metals in rivers of Lativia. Science of the Total Environment 262 (1-2): 175-184.

17. Norrgren L., Pettersson U.R.N.S. \& Bergquist P.A. (2000). Environmental monitoring of the Kafue River located in the upper belt of Zambia. Archives of Environmental Contamination \& Toxicology 38(3): 334-341.

18. Senarathne P. \& K.A.S. Pathiratne (2007). Accumulation of heavy metals in a food fish Mystus gulio inhabiting Bolgoda Lake, Sri Lanka. Sri Lanka Journal of Aquatic Sciences 12: 61-76.

19. Demirak A. Yilmaz F., Tuna A.L. \& Ozdemir N. (2005). Heavy metals in water sediment and tissues of Leuciscus cephalus from a stream in southwestern Turkey. Chemosphere 63(9):1451-1358.

20. George S.G. \& Young P. (1986). The time course effects of cadmium and 3-methylcholanthrene on activities of enzymes of xenobiotic metabolism and metallothionein levels in the plaice, Pleuronectes platessa. Comparative Biochemistry \& Physiology 83 C(1): 37-44.

21. George S.G. (1989). Cadmium effects on plaice liver xenobiotic and metal detoxication systems: dose response. Aquatic Toxicology 15(4): 303-310.

22. Ueng Y.F., Liu C., Lai C.F., Meng L.M, Hung Y.Y. \& Ueng T.H. (1996). Effects of cadmium and environmental pollution on metallothionein and cytochrome P450 in tilapia. Bulletin of Environmental Contamination \& Toxicology 57(1):125-131.

23. Wu S.M., Weng C.F., Yu M.J., Lin C.C., Chen S.T. \& Hwang J.C. (1999). Cadmium inducible metallothionein in tilapia, Oreochromis mossambicus. Bulletin of Environmental Contamination \& Toxicology 62(6):758768.

24. Cheung A.P.L., Lam T.H.J. \& Chan K.M. (2004). Regulation of tilapia metallothionein gene expression by heavy metal ions. Marine Environment Resarch 58(2-5):389-394.

25. Cosson R.P. (1994). Heavy metal intracellular balance and relationship with metallothionein induction in the 
liver of carp after contamination by silver, cadmium, and mercury following or not pretreatment by zinc. BioMetals 7(1):9-19.

26. Bozcaarmutlu A. \& Arinc E. (2004). Inhibitory effects of divalent metal ions on liver microsomal 7-ethoxyresorufin O-deethylase (EROD) activity of leaping mullet. Marine Environmental Research 58 (2-5): 521-524.

27. Basha P.S. \& Rani A.U. (2003). Cadmium induced antioxidant defence mechanism in freshwater teleost Oreochromis mossambicus (Tilapia). Ecotoxicology \& Environmental Safety 56(2): 218-221.

28. Payne J.F., Mathieu A., Melvin W. \& Fancey L.L. (1996). Acetylcholinesterase, an old biomarker with a new future?
Field trials in association with two urban rivers and a paper mill in New Foundland. Marine Pollution Bulletin 32(2): 225-231.

29. Pathiratne A. \& George S.G. (1998). Toxicity of malathion to Nile tilapia, Oreochromis niloticus and modulation by other environmental contaminants. Aquatic Toxicology $\mathbf{4 3}$ (4): 261-271.

30. Coğun H.Y., Yüzereroğlu T.A. \& Kargin F. (2003). Accumulation of copper and cadmium in small and large Nile tilapia, Oreochromis niloticus. Bulletin of Environmental Contamination \& Toxicology 71(6): 1265-1271. 